\author{
Jurnal E-Bis (Ekonomi-Bisnis) \\ Vol. 5 No. 2 (2021) pp.543-552 \\ https://jurnal.politeknik-kebumen.ac.id/index.php/E-Bis \\ p-ISSN : 2580-2062 e-ISSN : 2622-3368
}

\title{
Pengaruh Motivasi Kerja dan Disiplin Kerja Terhadap Efektivitas Selama Pandemi Covid-19 Pada Badan Penanggulangan Bencana Daerah Provinsi Jawa Timur.
}

\author{
Syifananda Putri Fianta ${ }^{\mathbf{1}^{*}}$, Mei Retno Adiwati ${ }^{\mathbf{2}}$, Endang Iryanti ${ }^{\mathbf{3}}$ \\ ${ }^{123}$ Prodi Manajemen, Fakultas Ekonomi dan Bisnis, Universitas Pembangunan Nasional \\ "Veteran" Jawa Timur, Indonesia \\ *Email : fiantaputri@gmail.com \\ Doi : https://doi.org/10.37339/e-bis.v5i2.746
}

Diterbitkan oleh Politeknik Dharma Patria Kebumen

\section{Info Artikel}

Diterima :

2021-10-22

Diperbaiki :

2021-10-24

Disetujui :

2021-10-28

\begin{abstract}
ABSTRAK
Badan Penanggulangan Bencana Daerah atau yang biasa disingkat dengan BPBD adalah suatu badan pemerintahan yang bertugas untuk melakukan penanggulangan dan penanganan bencana alam yang diharuskan untuk selalu memberikan informasi bencana dengan cepat, tepat, dan akurat. Namun Pandemi SARS-CoV-2 sekarang ini memiliki dampak yang sangat besar terhadap segala jenis pekerjaan yang mengakibatkan rendahnya semangat kerja yang dimiliki oleh para karyawan. Maka sebab itu penting bagi BPBD Provinsi Jatim untuk menjaga sekaligus meningkatkan motivasi dan disiplin pegawai di masa sulit seperti ini. Penelitian ini bertujuan untuk melihat bagaimana terjadinya pengaruh motivasi kerja dan disiplin kerja terhadap efektivitas kerja pada BPBD Provinsi Jatim. Populasi pada penelitian ini berjumlah 96 orang dengan sampel penelitian menggunakan teknik simple random sampling yang berjumlah 49 orang. Data primer yang digunakan untuk penelitian akan diolah menggunakan SmartPLS. Dalam penelitian ini mengungkapkan adanya pengaruh positif dari motivasi kerja dan disiplin kerja terhadap efektivitas kerja pada BPBD Provinsi Jawa Timur.

Kata Kunci : Motivasi Kerja, Disiplin Kerja, Efektivitas Kerja, Pandemi Covid-19
\end{abstract}

\section{ABSTRACT}

The Regional Disaster Management Agency or commonly abbreviated as $B P B D$ is a government agency tasked with managing and handling natural disasters that are required to always provide disaster information quickly, precisely, and accurately. However, the current Covid-19 pandemic has had a huge impact on all types of work, resulting in low morale among employees. Therefore, it is important for the BPBD of East Java Province to maintain and increase employee motivation and discipline in difficult times like this. This study aims to see how the effect of work motivation and work discipline on work effectiveness at BPBD East Java Province. The population in this study amounted to 96 people with the research sample using simple random sampling technique totaling 49 people. Primary data used for research will be processed using SmartPLS. This study reveals a positive influence of work motivation and work discipline on work effectiveness at BPBD East Java Province.

Key Words : Motivation, Discipline, Effectiveness, Covid-19 Pandemic 


\section{PENDAHULUAN}

Hidup di era serba modern seperti sekarang ini menuntut kita untuk dapat menguasai segala hal baru yang berdampingan dengan kehidupan kita saat ini. Keadaan menuntut kita untuk bisa menjadi seseorang yang dapat diandalkan disegala situasi terutama saat kita telah menjadi salah satu pegawai tetap sebuah perusahaan maupun pegawai pemerintahan. Pekerjaan dengan teknologi secanggih apapun tidak akan berjalan dengan sendirinya tanpa bantuan sumber daya manusia yang ada di dalam suatu organisasi tersebut. Tenaga kerja adalah suatu hal yang penting dalam sebuah perusahaan yang apabila tenaga kerja di dalam suatu perusahaan tidak mempunyai dedikasi yang tinggi dalam bekerja maka perusahaan tersebut akan sulit untuk mencapai tujuannya. Tenaga kerja adalah seseorang yang mengerahkan kemampuan, keahlian, dan tenaga untuk melakukan sebuah pekerjaan dan mendapat balas jasa. Dengan adanya sumber daya manusia yang berdedikasi baik dan unggul, maka pelayanan yang akan diberikan kepada masyarakat pun akan semakin baik pula.

Selain pemberian arahan dan pengetahuan serta tata cara agar pegawai dapat melakukan penanggulangan secara efektif, faktor lain yang mempengaruhi efektivitas kerja adalah motivasi pegawai dalam bekerja. Menurut (Effendi \& Yogie, 2019) Motivasi Kerja diartikan sebagai salah satu perasaan naluri di dalam diri seseorang untuk mendorong mereka dalam melalukan tugas dan kewajibannya dalam pencapaian tujuan perusahaan yang telah ditetapkan. Pegawai yang memiliki motivasi kerja yang baik akan senantiasa bersemangat dalam bekerja dan rela memberikan sebagian besar waktunya untuk membantu perusahaan dalam mencapai tujuannya.(issalillah, 2019).

Setelah Motivasi Kerja, terdapat juga satu hal lain yang bisa mempengaruhi efektivitas kerja yaitu kedisiplinan pegawai dalam bekerja. Menurut (Malka et al., 2020) Disiplin merupakan sikap taat dalam mentaati seluruh aturan dalam perusahaan. Pegawai yang memiliki disiplin kerja yang tinggi sebagian besar adalah pegawai yang memiliki dedikasi yang tinggi dalam bekerja. Dedikasi yang tinggi tersebut dapat menghasilkan hasil yang baik untuk perusahaan karena pegawai yang memiliki disiplin kerja yang tinggi akan mempercepat perusahaan untuk mencapai tujuan mereka karena pegawai yang disiplin pasti akan selalu mentaati peraturan yang ada di dalam perusahaan tersebut. Disiplin diperlukan baik dari pemangku kepentingan maupun organisasi (FIRDIANSYAH, 2019) Dalam hal kedisiplinan diatas, hal tersebut sangat penting untuk selalu ditanamkan kepada seluruh pegawai dalam BPBD Provinsi Jawa Timur guna menanamkan kedisiplinan dalam hal ketepatan waktu datang dan pulang kerja, ketepatan waktu dalam menanggulangi bencana agar tidak memperburuk keadaan, serta kepatuhan dalam melaksanakan peraturan yang sudah ditetapkan.

Pada awal bulan maret 2020, masyarakat digemparkan dengan fenomena SARS-CoV-2 atau Virus Corona. Seperti yang telah kita ketahui bahwa SARS-CoV-2 ini adalah virus yang mematikan karna telah merenggut banyak korban jiwa, oleh sebab itu pemerintah segera mengambil kebijakan baru terhadap seluruh bidang pekerjaan di indonesia yang terdampak karena adanya pandemi tersebut. Kebijakan tersebut adalah dengan melaksanakan sistem kerja secara work from home atau bekerja dari rumah. Hal tersebut pasti menimbulkan dampak terhadap pegawai Badan Penanggulan Bencana Provinsi Jawa Timur yang mana pekerjaan mereka menuntut mereka untuk tetap terjun langsung maupun kontak lansung dengan 
masyarakat yang terdampak bencana.

Berdasarkan latar belakang diatas, maka peneliti mengambil judul "Pengaruh Motivasi Kerja dan Disiplin Kerja Terhadap Efektivitas Kerja Selama Pandemi Covid-19 Pada Badan Penanggulangan Bencana Daerah Provinsi Jawa Timur”.

\section{KAJIAN PUSTAKA}

\subsection{Motivasi Kerja}

Motivasi kerja sendiri memiliki arti rasa semangat dalam diri seseorang untuk senantiasa melakukan kegiatan dengan intensitas dan rasa sukarela yang tinggi yang dapat mempengaruhi hasil mereka dalam bekerja. Menurut (Aziz, 2017) motivasi kerja diartikan sebagai faktor psikologis seseorang yang dapat mempengaruhi mereka dalam bekerja dan mewujudkan tujuan perusahaan. Sesuatu yang menggerakkan diri seseorang untuk mengerahkan keterampilan dan keahlian guna menghasilkan suatu hasil kerja yang optimal untuk mencapai tujuan perusahaan (Arisanti et al., 2019).

\subsection{Disiplin Kerja}

Menurut Disiplin merupakan faktor pendorong alami dari dalam diri seseorang untuk selalu patuh dalam mentaati peraturan yang telah dibuat oleh perusahaan (Saleh \& Utomo, 2018). Rasa gairah yang mendorong seseorang untuk melakukan pekerjaan sebagai cerminan besarnya tanggung jawab mereka terhadap pekerjaan tersebut guna mencapai tujuan perusahaan, masyarakat, dan karyawan itu sendiri (Suwanto, 2019)

\subsection{Efektivitas Kerja}

Menurut Mardiasmo (2017: 134) Efektivitas merupakan sebuah tolak ukur dalam melihat apakah perusahaan tersebut berhasil atau justru menuai kegagalan dalam mencapai tujuan yang telah dibuat. Suatu perusahaan dapat dikatakan efektif jika kontribusi pegawai dalam bekerja sudah memenuhi syarat untuk mencapai tujuan perusahaan, maka hal tersebut juga dapat dikatakan proses kerja di dalam perusahaan semakin efisien.

\subsection{Pandemi Covid-19}

Pada 11 Maret 2020, Organisasi Kesehatan Dunia (WHO) mengumumkan pandemi SARS-CoV-2 atau Virus Corona. Pandemi berarti penyakit yang mengjangkit manusia secara menyeluruh. Penyakit ini sudah ditetapkan sebagai penyakit yang berpotensi menginfeksi seluruh populasi manusia. Hal ini membawa dampak yang cukup serius pada segala kegiatan tatap muka yang berdampak pula terhadap segala pekerjaan maupun pendidikan karena kita dipaksa untuk membatasi segala kegiatan yang berada di luar rumah.

\subsection{Kerangka Berpikir}

Motivasi kerja merupakan daya pendorong yang berasal dari naluri setiap individu untuk melakukan segala kegiatan yang membutuhkan keahlian, ketekunan, maupun semangat mereka dalam melakukan pekerjaan. Rendahnya Motivasi Kerja pada BPBD Provinsi Jatim dilihat dari 
kurangnya kedekatan antara pimpinan dengan pegawai dan kurangnya intensitas pimpinan untuk memotivasi pegawainya yang mengakibatkan menurunnya semangat kerja pegawai yang diakibatkan rasa kurang termotivasi dalam bekerja mengakibatkan hasil kerja tidak maksimal sehingga berdampak pula terhadap efektivitas kerja yang dihasilkan. Faktor Pandemi Covid-19 yang juga memberi dampak terhadap rendahnya motivasi kerja pegawai dikarenakan pada saat pandemi seperti ini mereka tidak bisa bebas atau lebih tepatnya banyak keterbatasan untuk melakukan kegiatan yang mengharuskan mereka untuk terjun langsung kepada masyarakat yang terdampak bencana, maupun kegiatan pelatihan penanggulangan bencana yang pada saat ini tidak bisa dilakukan secara langsung melainkan hanya melalui penjelasan teori saja melalui platform online.

Sebaiknya jika motivasi kerja pegawai tinggi, kesiapsiagaan dari para pegawai ketika menanggulangi bencana akan dilakukan tepat pada waktunya dan mengurangi resiko memperparahnya keadaan yang terdampak bencana karena tidak bisa langsung tertangani dengan cepat dan dengan cara yang benar. Hal tersebut memperlihatkan bahwa efektivitas kerja dapat ditingkatkan dengan motivasi kerja yang tinggi dari pegawainya. Motivasi pegawai pada BPBD Provinsi Jatim untuk melakukan pekerjaannya dengan tepat waktu dan dengan cara penanganan yang tepat karena diharuskan untuk melakukan pelayanan terbaik kepada masyarakat dan juga menunaikan tanggung jawab sebagai Aparatur Sipil Negara yang mana pelayanan terbaik kepada masyarakat adalah tujuan dari pekerjaan yang mereka lakukan.

Disiplin adalah suatu rasa dan perbuatan yang membuat mereka untuk selalu mentaati aturan yang sudah di sah kan di suatu perusahaan. Aturan yang dimaksudkan adalah mengenai absensi dan keterlambatan masuk kerja. Menurunnya tingkat kedisiplinan dari pegawai BPBD Provinsi Jatim terlihat dari data absensi mengenai banyaknya pegawai yang tidak disiplin saat bekerja pada pandemi SARS-CoV-2 seperti sekarang ini. Banyaknya keterbatasan yang dibuat oleh pemerintah guna mengurangi penyebaran SARS-CoV-2, mengakibatkan pegawai terkesan menggampangkan pekerjaannya yang berdampak pada besarnya prosentase terlambat pada data absensi pegawai. Hal ini mengindikasikan belum optimalnya efektivitas kerja pegawai pada BPBD Provinsi Jatim yang memiliki pengaruh oleh faktor Disiplin Kerja.

Sebaiknya ketika tingkat kedisiplinan pegawai tinggi, penanganan penanggulangan bencana serta kesiapsiagaan dalam pencegahan terhadap bencana yang akan datang dapat dilakukan tepat pada waktunya, tidak akan terjadi keterlambatan dalam memberikan informasi mengenai pencegahan bencana maupun penanganan terhadap korban bencana. Hal diatas membuktikan bahwa efektivitas kerja dapat ditingkatkan dengan Disiplin Kerja yang tinggi. Dari teori yang sudah dijelaskan dibuatlah sketsa pengaruh antara motivasi kerja dan disiplin kerja terhadap efektivitas kerja seperti pada gambar berikut: 


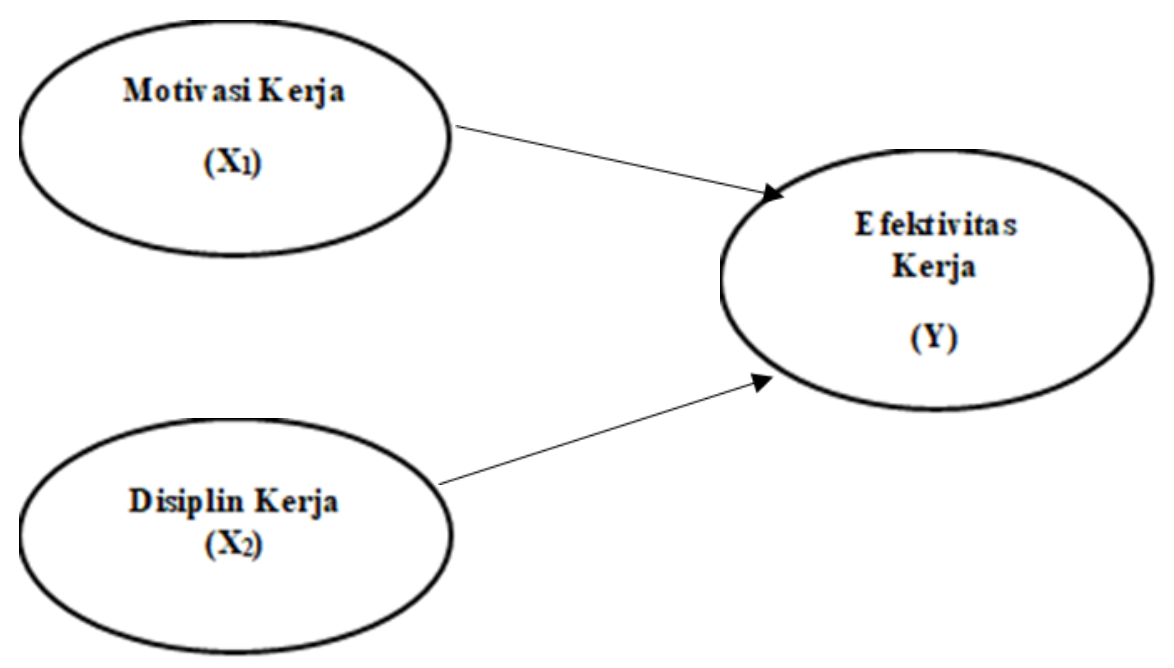

\subsection{Hipotesis Penelitian}

1. H1 : Ada pengaruh Positif Motivasi Kerja terhadap Efektivitas Kerja selama Pandemi Covid-19 pada BPBD Provinsi Jawa Timur.

2. H2 : Ada pengaruh Positif Disiplin Kerja terhadap Efektivitas Kerja selama Pandemi Covid-19 pada BPBD Provinsi Jawa Timur.

\section{METODE PENELITIAN}

Jenis dalam penelitian ini menggunakan deskriptif kuantitatif yang kemudian diolah melalui metode PLS (Partial Least Square) menggunakan program SmartPLS 3.0. Data untuk penelitian ini di dapatkan dengan cara menyebarkan angket atau kuesioner berskala likert. Populasi pada penelitian ini adalah pegawai yang merupakan anggota pada BPBD Provinsi Jatim yang berjumlah 96 orang. Sampel diperoleh menggunakan Simple random sampling atau sampel yang mana pemilihannya dilakukan secara acak dengan mengabaikan tingkatan yang terdapat pada populasi tersebut (Sugiyono, 2007). Adapun rumus slovin di gunakan sebagai penentu ukuran sampel pada penelitian ini yaitu:

\section{Rumus sampel: Rumus slovin}

$$
n=\frac{N}{1+N e^{2}}
$$

Jumlah sampel dari populasi yang digunakan menurut rumus diatas sebanyak 48,9 orang. Dengan dilakukannya pembulatan, maka jumlah sampel yang diterapkan pada penelitian ini adalah sebanyak 49 responden. Sumber data diperoleh melalui penyebaran kuesioner secara langsung pada pegawai BPBD Provinsi Jatim. 


\section{HASIL DAN PEMBAHASAN}

\subsection{Deskripsi Demografi Responden}

Data untuk penelitian ini dikumpulkan dari berbagai karakteristik responden yang dikategorikan menurut jenis kelamin, usia, dan lama bekerja. Berdasarkan dari ketiga karakteristik tersebut maka ditemukan bahwa penelitian ini di dominasi oleh pria (28 orang atau $51,7 \%$ ), berasal dari kelompok usia 17-26 tahun (5 orang atau 10,2\%), usia 27-36 tahun (30 orang atau 61,2\%), usia 37-46 tahun (14 orang atau 28,6\%), lama bekerja kurang dari satu tahun (14 orang atau $28,6 \%$ ), lama bekerja dalam kurun waktu satu tahun (35 orang atau $71,4 \%$ ).

\subsection{Uji Outer Model}

\section{Gambar 1}

Outer Model PLS Dengan Factor Loading, Path Coefficients Dan R-Square

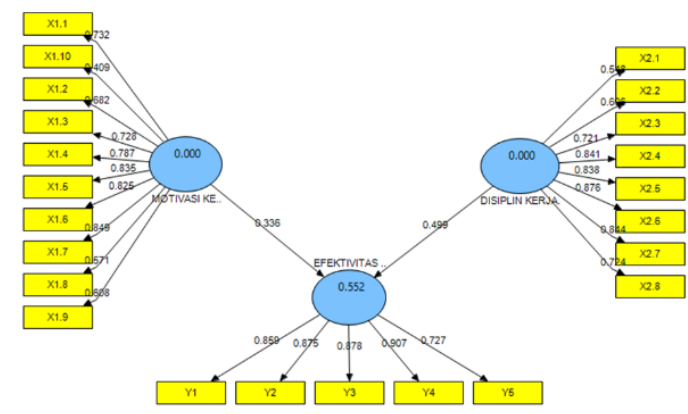

Gambar diatas menunjukkan besaran nilai factor loading masing-masing indikator. Melalui gambar itu pula dapat diketahui bahwa seluruh indikator dalam penelitian ini memperoleh nilai factor loading diatas 0.5 yang menunjukkan bahwa seluruh indikator memiliki validitas yang baik dan mampu dijadikan pengukur tiap variabel.

Tabel 1

Average variance extracted (AVE)

\begin{tabular}{ll}
\hline & AVE \\
\hline DISIPLIN KERJA (X2) & 0.575291 \\
EFEKTIVITAS KERJA (Y) & 0.724525 \\
MOTIVASI KERJA (X1) & 0.542012 \\
\hline
\end{tabular}

Berdasarkan tabel diatas menunjukkan bahwa output pengujian AVE untuk variabel Motivasi Kerja (X1) yaitu nilainya 0.542012, variabel Disiplin Kerja (X2) dengan nilai 0.575291, dan Efektivitas Kerja (Y) dengan nilai 0.724525. Hasil tersebut menunjukkan bahwa seluruh variabel mendapatkan nilai lebih dari 0,5 yang berarti seluruh variabel pada penelitian ini telah bervaliditas baik. 
Tabel 2

Composite Reliability

\begin{tabular}{ll}
\hline & Composite Reliability \\
\hline DISIPLIN KERJA (X2) & 0.913734 \\
EFEKTIVITAS KERJA (Y) & 0.928985 \\
MOTIVASI KERJA (X1) & 0.921093 \\
\hline
\end{tabular}

Berdasarkan tabel diatas menunjukkan bahwa hasil pengujian Composite Reability Motivasi Kerja (X1) mendapatkan nilai 0.921093, variabel Disiplin Kerja (X2) 0.913734, dan Efektivitas Kerja (Y) memperoleh nilai 0.928985, yang berarti seluruh variabel tersebut telah mendapatkan nilai (skor) Composite Reliability diatas batas ideal yaitu 0.70 sehingga dengan demikian keseluruhan variabel dinilai telah reliabel.

\subsection{Uji Inner Model}

Pengujian Inner Model pada umumnya bisa ditemukan pada besaran nilai R-Square atau yang kerap kali disebut dengan uji goodness-fit model. Besaran nilai R-Square ini dapat menjelaskan seberapa besar kemampuan variabel eksogen (independent variable) dalam menafsirkan variabel endogen (dependent variable).

Tabel 3

R-Square

\begin{tabular}{|c|}
\hline R Square \\
\hline DISIPLIN KERJA (X2) \\
\hline EFEKTIVITAS KERJA (Y) 0.556569 \\
\hline MOTIVASI KERJA (X1) \\
\hline
\end{tabular}

Tabel tersebut menunjukkan bahwa besaran nilai atau skor R-Square dari variabel Efektivitas Kerja adalah 0.556569. Sehingga hal ini memiliki makna bahwa melalui variabel Motivasi Kerja dan Disiplin Kerja dapat menjelaskan terjadinya fenomena dalam Efektivitas Kerja dengan persentase sebesar 55,65\%. Sementara 44,35\% lainnya mampu diterangkan oleh variabel lain selain Motivasi Kerja dan Disiplin Kerja.

\subsection{Uji Hipotesis}

Tabel 4

Path Coefficients (Mean, STDEV, T-Values)

\begin{tabular}{|c|c|c|c|c|c|}
\hline & $\begin{array}{c}\text { Path } \\
\text { Coefficients } \\
(\text { O) } \\
\end{array}$ & $\begin{array}{c}\text { Sample } \\
\text { Mean (M) }\end{array}$ & $\begin{array}{l}\text { Standard } \\
\text { Deviation } \\
\text { (STDEV) }\end{array}$ & $\begin{array}{c}\text { Standard } \\
\text { Error } \\
\text { (STERR) }\end{array}$ & $\begin{array}{c}\text { T Statistics } \\
(\mid \text { O/STERR } \mid)\end{array}$ \\
\hline $\begin{array}{l}\text { MOTIVASI KERJA (X1) -> } \\
\text { EFEKTIVITAS KERJA (Y) }\end{array}$ & 0.339021 & 0.327928 & 0.102656 & 0.102656 & 3.302486 \\
\hline
\end{tabular}




\section{DISIPLIN KERJA (X2) -> EFEKTIVITAS KERJA (Y)

\section{Pengaruh Motivasi Kerja terhadap Efektivitas Kerja}

Menurut hasil perolehan uji hipotesis pada bagian sebelumnya, maka didapati bahwa Motivasi Kerja mempunyai pengaruh positif atas menurunnya Efektivitas Kerja pegawai selama pandemi SARS-Cov-2 pada BPBD Provinsi Jatim. Dengan skor koefisien jalur yang bernilai 0.339021 , serta skor $T$-statistic yang bernilai $3.302486>1,96$, sehingga hal ini dapat dijadikan alasan dalam menerima hipotesis dengan arah positif signifikan. Hasil ini diperoleh dari kurangnya kedekatan antara pimpinan dengan pegawai dan kurangnya intensitas pimpinan untuk memotivasi pegawainya yang mengakibatkan menurunnya semangat kerja pegawai yang diakibatkan rasa kurang termotivasi dalam bekerja mengakibatkan hasil kerja tidak maksimal sehingga berdampak pula terhadap efektivitas kerja yang dihasilkan. Faktor Pandemi Covid-19 yang juga memberi dampak terhadap rendahnya motivasi kerja pegawai dikarenakan pada saat pandemi seperti ini mereka tidak bisa bebas atau lebih tepatnya banyak keterbatasan untuk melakukan kegiatan yang mengharuskan mereka untuk terjun langsung kepada masyarakat yang terdampak bencana, maupun kegiatan pelatihan penanggulangan bencana yang pada saat ini tidak bisa dilakukan secara langsung melainkan hanya melalui penjelasan teori saja melalui platform online. Penelitian ini mempunyai hasil yang sejalan dengan hasil penelitian milik Chandra Andika Hadi Purnomo, M. Djudi, dan Yuniadi Mayowan (2017), Budi Rismayadi dan Mumun Maemunah (2016), Junaidi Hasan dan Ahmad Sahputra (2019) yang terdapat pengaruh positif antara Motivasi Kerja terhadap Efektivitas Kerja pegawai.

\section{Pengaruh Disiplin Kerja terhadap Efektivitas Kerja}

Menurut hasil perolehan uji hipotesis pada bagian sebelumnya, maka didapati bahwa Disiplin Kerja memiliki pengaruh yang positif atas menurunnya Efektivitas Kerja selama pandemi covid-19 pada BPBD Provinsi Jatim. Dengan skor koefisien jalur yang bernilai 0.503184 , serta skor T- statistic yang bernilai $6.087598>1,96$, sehingga hal ini dapat dijadikan alasan dalam menerima hipotesis dengan arah positif signifikan. Hasil ini diperoleh dari menurunnya tingkat kedisiplinan dari pegawai BPBD Provinsi Jatim terlihat dari data absensi mengenai banyaknya pegawai yang tidak disiplin saat bekerja pada saat pandemi SARS-Cov-2 seperti sekarang ini. Banyaknya keterbatasan dibuat oleh pihak berwenang guna mengurangi penyebaran virus corona, mengakibatkan pegawai terkesan menggampangkan pekerjaannya yang berdampak pada besarnya prosentase terlambat pada data absensi pegawai.Hal ini mengindikasikan belum optimalnya efektivitas kerja pegawai pada BPBD Provinsi Jatim yang dipengaruhi oleh faktor Disiplin Kerja. Penelitian ini mempunyai hasil yang sejalan dengan hasil penelitian milik Junaidi Hasan dan Ahmad Saputra (2019), Rima Dwiningtyas dan Bambang Swasto Sunuharyo (2018), Chandra Andika Hadi Purnomo, M. Djudi, dan Yunaidi Mayowan (2017) yang juga memperoleh temuan bahwa terdapat pengaruh positif antara Disiplin Kerja terhadap Efektivitas Kerja pegawai.

\section{KESIMPULAN}


Dilakukannya penelitian ini bertujuan untuk melihat bagaimana pengaruh Motivasi Kerja dan Disiplin Kerja terhadap Efektivitas Kerja selama pandemi SARS-CoV-2 pada BPBD Provinsi Jatim. Setelah mengetahui beberapa hal diatas, penjelasan tersebut dapat diartikan bahwa motivasi kerja dan disiplin kerja memberikan pengaruh positif signifikan terhadap efektivitas kerja. Hal ini menjelaskan bahwa semakin meningkatnya Motivasi Kerja dan Disiplin Kerja dalam diri pegawai maka akan semakin meningkat pula Efektivitas Kerja sebuah perusahaan, sehingga akan dapat meningkatkan Efektivitas Kerja dalam Badan Penanggulangan Bencana Daerah tersebut pula.

\section{SARAN}

Penelitian ini juga memiliki keterbatasan yaitu diantaranya adalah jumlah sampel yang digunakan tidak banyak, sehingga diharapkan untuk peneliti selanjutnya untuk menambahkan jumlah sampel pada penelitian mereka agar hasil yang diperoleh lebih akurat. Selain itu peneliti selanjutnya dapat menambahkan atau menggunakan faktor yang dapat mempengaruhi efektivitas kerja seperti kinerja karyawan, kepuasan kerja, lingkungan kerja, kepemimpinan, dan lainnya.

\section{REFERENSI}

Effendi, M., \& Yogie, F. (2019). Pengaruh Motivasi dan Disiplin Kerja terhadap Kinerja Karyawan. Journal of Management and Bussines (JOMB), 1(1), 88-98.

Issalillah, fayola. (2019). Pengaruh Motivasi Kerja Dan Disiplin Kerja Terhadap Kinerja Karyawan. 2.

Malka, A. E. I., Mus, A. R., \& Lamo, M. (2020). Pengaruh Disiplin Kerja, Motivasi Kerja, dan Kemampuan Kerja Terhadap Kinerja Pegawai. CESJ: Center Of Economic Students Journal, 3(1), 73-89.

FIRDIANSYAH, M. (2019). Pengaruh Disiplin Dan Motivasi Terhadap Kinerja Karyawan Cv. Andalah Jaya Tugumulyo. 2(3), 351-360.

Aziz, M. A. (2017). Pengaruh Motivasi Kerja, Disiplin Kerja Dan Lingkungan Kerja Terhadap Kinerja Melalui Kepuasan Kerja Pada Pegawai Puskesmas Kecamatan Balapulang Kabupaten Tegal. Multiplier: Jurnal Magister Manajemen, 1(1), 99-108.

Arisanti, K. D., Santoso, A., \& Wahyuni, S. (2019). Pengaruh Motivasi Kerja Dan Disiplin Kerja Terhadap Kinerja Karyawan Pada PT Pegadaian (Persero) Cabang Nganjuk. JIMEK: Jurnal Ilmiah Mahasiswa Ekonomi, 2(1), 101.

Saleh, A. R., \& Utomo, H. (2018). Pengaruh Disiplin Kerja, Motivasi Kerja, Etos Kerja Dan Lingkungan Kerja Terhadap Produktivitas Kerja Karyawan Bagian Produksi Di Pt. Inko Java Semarang. Among Makarti, 11(1), 28-50.

Suwanto, S. (2019). Pengaruh Disiplin Kerja Dan Motivasi Kerja Terhadap Kinerja Karyawan Pada Rumah Sakit Umum Tangerang Selatan. JENIUS (Jurnal Ilmiah Manajemen Sumber Daya Manusia), 3(1), 16. 
Andika, R. (2019). Pengaruh Motivasi Kerja dan Persaingan Kerja Terhadap Produktivitas Kerja Melalui Kepuasan Kerja sebagai Variabel Intervening Pada Pegawai Universitas Pembangunan Panca Budi Medan. Jumant, 11(1), 189-206.

Aldi, Y., \& Susanti, F. (2019). Pengaruh Stress Kerja Dan Motivasi Kerja Terhadap Prestasi Kerja Karyawan Pada PT. Frisian Flag Indonesia Wilayah Padang.

Ardian, N. (2019). Pengaruh Insentif Berbasis Kinerja, Motivasi Kerja, Dan Kemampuan Kerja Terhadap Prestasi Kerja Pegawai UNPAB. JEpa, 4(2), 119-132.

Saputra, T. (2016). Pengaruh Motivasi Kerja Terhadap Disiplin Kerja Pegawai Pada Dinas Pemuda Dan Olahraga Provinsi Riau. Jurnal Niara, 8(2), 50-60.

Ekhsan, M. (2019). Pengaruh Motivasi dan Disiplin Kerja terhadap Kinerja Karyawan. Optimal: Jurnal Ekonomi dan Kewirausahaan, 13(1), 1-13.

Sutrisno, S., Fathoni, A., \& Minarsih, M. M. (2016). Pengaruh motivasi dan disiplin kerja terhadap kinerja pegawai di kantor satuan polisi pamong praja kota Semarang. Journal of Management, 2(2).

Tanjung, H. (2017). Pengaruh Disiplin Kerja Dan Motivasi Kerja Terhadap Prestasi Kerja Pegawai Pada Dinas Sosial Dan Tenaga Kerja Kota Medan. Jurnal Ilmiah Manajemen Dan Bisnis, 15(1).

Kristianti, L. S., Affandi, A., Nurjaya, N., Sunarsi, D., \& Rozi, A. (2021). Pengaruh Motivasi Dan Disiplin Kerja Terhadap Kinerja Pegawai Pada Dinas Pariwisata Purwakarta. Jurnal Ilmiah

Esthi, R. B., \& Marwah, Y. N. (2020, March). Kinerja karyawan: motivasi dan disiplin kerja pada PT. Asahi indonesia. In FORUM EKONOMI (Vol. 22, No. 1, pp. 130-137). 